\title{
Internal Procedures on Work-related Bullying Complaints Critical Points
}

\author{
Manuel Velázquez \\ Faculty of Industrial Relations, University of the Basque Country, Spain \\ Basque Observatory on Bullying and Discrimination, Spain
}

Copyright $(2016$ by authors, all rights reserved. Authors agree that this article remains permanently open access under the terms of the Creative Commons Attribution License 4.0 International License

\begin{abstract}
Internal procedures on bullying complaints are nowadays a common feature in the practice of industrial relations in many countries and international organisations. The legal grounds to implement them can be the employers' duty of care within the framework of occupational safety and health legislation or as a mechanism of internal remediation for the protection of labour human rights. Procedures are not always provided by legal rules but they can facilitate employers how to cope with these behaviours. The nature of these procedures is not disciplinary but preventive, their aim is to avoid bullying. Requirements so that procedures can work efficiently are that workers can participate on them, that persons who manage procedures should be neutral, trained and have enough power to carry out their tasks, to proceed with necessary discretion to protect the dignity and privacy of the Parties involved and to insert operative mechanisms in order to avoid inappropriate complaints, protect complainants and witnesses, prevent interruptions and delays and adopt resolutions and measures when bullying has occurred.
\end{abstract}

Keywords Legal Grounds, Nature, Requirements for Efficiency

\section{Legal Grounds to Implement Procedures on Bullying Complaints}

Implementation of internal procedures on bullying or harassment complaints in companies is nowadays a common feature in the legal practice of many countries and international organisations.

Currently, the grounds to implement them in national laws can be the employers' duty of care within the framework of occupational safety and health legislation, as a mechanism of remediation for the protection of labour human rights in companies and as a tool established by companies to protect their criminal responsibility, as legal persons, in offences committed by their employees. We are going to analyse briefly all of them.

\subsection{Employers' Duty of Care on Occupational Safety and Health}

We rely on the scientific evidence-based recognition that the work-related bullying behaviours and other forms of psychological violence at work can cause or aggravate mental and physical disorders in workers' health.

Stress and violence are usually considered the main consequences of the exposure to psychosocial risks factors at work and increasingly many States, especially in the scope of the European Union, are setting standards and soft-law instruments to prevent them.

However, unlike other psychosocial risks such as work-related stress, bullying is not easy to identify through the normal practice of risk prevention management systems. The main reason is that bullying usually affects one person and the most of assessment methods on psychosocial risks, especially in big companies, are based on questionnaires or surveys which entail the use of quantitative techniques to identify risk factors. Psychosocial hazards are therefore identified when the number of people affected is sufficiently clear in statistical grounds.

For that reason, one of the most appropriate ways to identify work-related bullying is the complaint of the worker affected or the complaint of his or her colleagues. When employers know or should know that one or more workers are subject to bullying behaviours in their company they have the duty to protect their right to safety and health at work and adopt all suitable measures for this purpose.

In short, procedures on bullying complaints can play the role of an adequate tool to help employers intervene on bullying behaviours and ensure their duty of care with regard to their workers.

According to these principles, European countries such as Belgium has regulated in 2014 this kind of procedure in the Wellbeing at Work Act [1] and in Ireland the Government 
approved in 2007 a Code of Practice on the Prevention and Resolution of bullying at work [2] which included these procedures.

In America, the Canadian province of Ontario has provided in the Occupational Health and Safety Act (amended in 2009) [3], in Articles 32.0.2 and 32.0.6 about violence and harassment at work, that the employer should set out a program which include how to investigate and deal with incidents and complaints of workplace violence and harassment. Likewise in Colombia, the law 1010 [4] adopts measures to prevent, correct and punish the workplace bullying and among them Article 9 states that companies should include in their internal regulations procedures on bullying complaints.

\subsection{Human Rights Protection at Work}

However, bullying does not only affect occupational health and safety rights. It also entails the violation of human rights at work broadly recognised in many National Constitutions and national laws such as the right to dignity, the right to integrity (physical, psychological and moral) and moreover, in certain circumstances, the right to equal treatment and the right to privacy.

Employers have the duty to protect workers' human rights and in many countries the judgments of the courts have also enlarged this protection not only to cases of effective and real human rights violation but also to cases of serious, foreseeable and certain risk of violation. Employers have therefore the duty of preventing the violation of labour human rights at work acting with appropriate due diligence. The duty of care is not therefore an exclusive matter of the occupational health and safety laws.

Every country has developed its own legal doctrine about this issue. If we are looking for an international reference, we can rely on the Guiding Principles on Business and Human Rights approved by United Nations in 2011 [5]. They expressly include due diligence in order to ensure that relevant policies, legislation and regulations regarding respect for human rights are implemented (principle 4)

In such a way, principle 15 states that "in order to meet their responsibility to respect human rights, business enterprises should have in place policies and processes appropriate to their size and circumstances, including: (a) A policy commitment to meet their responsibility to respect human rights; (b) A human rights due diligence process to identify, prevent, mitigate and account for how they address their impacts on human rights and (c) Processes to enable the remediation of any adverse human rights impacts they cause or to which they contribute.

In the contents of this principle, three stages of the human rights management by companies are described:

- The start point would be a commitment or statement made by the employers about their intention to protect human rights in their companies.

- The second stage is prevention activity or due diligence. How the employers should identify, prevent, mitigate and account for how they address their adverse human rights impacts, as principle 17 clarifies afterward.

- Finally, the third stage is providing for their remediation through legitimate processes, as principle 22 states. Internal procedures on work-related bullying disputes would be therefore in this last stage of protection.

In a similar way, some national labour laws have also implemented procedures on bullying or harassment complaints. We can mention in this respect the legislation of some Canadian provinces on psychological bullying such as the Labour Standards Act in Quebec (Articles 81.18, 81.19 and 81.20) and some European national laws which implement the Directives 2000/78 and 2003/72 on Equal Treatment. For instance, Article 48 of the Spanish Law on Effective Equality for Women and Men approved in 2007 [6] requires all employers to implement these procedures on sexual harassment and sex-related harassment complaints.

In Spain and other European countries collective bargaining and the common practice in big companies have extended these procedures to all kinds of bullying and harassment behaviours.

Besides some soft-law instruments, such as some papers of International Organisations [7] and the European Framework Agreement on Violence and Harassment at Work [8] , signed by the European Social Partners in 2007, also recommend implementing internal procedures on bullying complaints.

In Spain, the Basque Observatory on Bullying and Discrimination has made guidelines about procedures for intervention and prevention of workplace bullying [9].

\subsection{Practical Reasons}

In any case, all these considerations reflect not so much the legal requirement of employers to implement procedures but their duty to react and protect affected workers when they know that bullying is taken place in their companies.

Procedures for complaints do not always exempt liability to employers. They are responsible when they know bullying behaviours and do nothing to avoid them. However, procedures can facilitate employers how to act before these situations if they want to be in accordance with the law.

Otherwise, if they have not any procedure or any tool in place, they should decide what to do in any case and improvise a way to cope with each situation when it arises.

\section{The Preventive Nature of These Procedures}

These procedures have not a disciplinary nature since their real aim is not to punish harassment but an intervention to prevent this behaviour from occurring. 
When bullying has already happened and prevention of further damages cannot be feasible, other legal procedures could be used by the offended person. For instance, when complaints arise just at the end of the employment relationship, or when facts have happened in the past and their recurrence is not already possible, these procedures have not any raison d'être. In these cases, developing procedures could became burdensome for companies and do not provide any improvement of working conditions for affected workers.

Another consequence of this preventive principle is that complaints based on simple suspicions or hints should always be admitted because, otherwise, whether agents consider that harassment must be already accomplished or there must be a clear evidence of bullying from the start of the process, prevention aims could not be achieved ever.

Actually, harassment behaviours have usually their origin in conflicts or disputes developed on scale that reach a point in which one of the Parties abuse of his position and the dispute becomes irreconcilable. Suitable time for intervention must be prior to the phase in which the conflict is already irreversible. For that reason, it is convenient to have flexibility in the admission of the complaints in order to prevent bullying.

Whatever the final outcome, this preventive aim of the procedure should not be forgotten and that occurs when it ends with a simple verdict of guilt or innocence of the person reported without taken preventive measures in order to mitigate psychosocial risks factors identified during the process or avoid recurrence. Procedures can be therefore a tool for identifying occupational health hazards and prevent them.

\section{Requirements for Efficiency of Procedures}

\subsection{Workers' Participation in Negotiating and Setting-up Procedures}

When there is not any specific regulation, employers may establish procedures without workers' participation or consultation.

If we consider these procedures as a preventive measure of occupational safety and health, European legislation requires employers to consult previously workers' representatives (Article 11 of the Framework Directive 89/391 on occupational safety and health [10]).

Regardless legal requirements, workers' participation and agreement on procedures imply clear advantages since they contribute to ensure their legitimacy. In these cases, procedures will probably be used by workers since they will be more confident in them.

\subsection{Conditions of the Persons Who Manage Procedures}

Persons who manage procedures should be neutral, trained and have enough power to carry out their tasks.

\subsubsection{Neutrality}

Neutrality involves that all parties should get an impartial hearing and fair treatment. That does not occur when the investigation or conduction is entrusted to the hierarchic of the person complained.

It does not happen either when this person complained belongs to the top management staff of the company, as it is usual in small businesses. In these cases, a subsidiary system of public procedures on bullying complaints could solve this problem, as it is foreseen in the legislation of Quebec.

\subsubsection{Training}

The lack of training or knowledge about bullying or harassment of those who manage the procedures could affect the proper understanding of the complaints and the nature and purpose of these procedures.

In Ireland the Code of Practice foresees specific mediators for these procedures, in Belgium legislation on wellbeing at work provides a "trusted person" to give advice and collaborate with the Parties and in the Ontario Guidelines on developing human rights policies and procedures establish an advisor for information and assistance to the people involved.

Sometimes companies look for external consultants in order to fix both problems of neutrality and training. These experts are usually trained but their neutrality is convenient to be ensured by the previous agreement of the parties or another equivalent mechanism.

In any case, the expert should not play the same role nor apply the same techniques than a mediator in labour disputes. The particularities of the bullying complaints should be taken into account since the position of the parties is not equal.

\subsubsection{Power}

Lastly, procedure managers should have sufficient powers to deal with the investigation and adopt appropriate preventive y protection measures in due course.

\subsection{Protection of Privacy}

In these types of procedures it is convenient to proceed with necessary discretion to protect the dignity and privacy of the parties involved.

Any kind of information should not be disclosed to people who are not involved in the case. Information should only be shared with those who need to know about it.

It is suitable that this rule is explicitly stated in writing for all persons involved. Confidentiality should also encompass witnesses in order to avoid reprisal and persecution.

However, it should be considered that knowledge on success stories can have a positive effect to encourage other workers to use these procedures and the employer could publish periodic reports for disclosing good results. 


\subsection{Operating Conditions}

Procedures should be managed with efficiency and effectiveness. Frequently, an anomalous management of these processes could highlight the problem of a lack of commitment of the employer in these forms of intervention. The basic operating conditions would be providing mechanisms in order to avoid inappropriate complaints, protecting complainants and witnesses, preventing interruptions and delays and adopting resolutions and measures when bullying has occurred.

\subsubsection{Avoiding Inappropriate Complaints}

It is quite frequent in all contexts that many complaints on bullying are not properly about this conduct. Sometimes they regard to labour conflicts or work-related stress situations. These complaints should always be dealt with by the employer but bullying complaints should have a specific treatment in order to protect the offended person and witnesses.

Furthermore, other complaints can be even spurious or illegitimate, especially when they are submitted by the offender as a counterattack against the offended person.

A previous analysis to admit or redirect complaints by a neutral instance could be a good deterrence to both problems.

\subsubsection{Protecting the Complainant and Witnesses}

Procedure managers should be able to adopt protective measures for the complainant and witnesses during the process in order to avoid reprisal or undue pressing from others. These measures could be paid leave of absence, moved to different workplace or location, etc.

\subsubsection{Preventing Interruptions and Delays}

Complaints should be investigated and dealt with timely and without undue delay. A time scale could be foreseen to avoid confusion and delaying manoeuvres in the form of appeals and complaints that may take time to be resolved.

Slowness in resolution is precisely one of the situations that implementation of these procedures intends to prevent.

\subsubsection{Adopting Resolutions and Measures When Bullying} Has Occurred

If harassment and violence has occurred, appropriate measures will be taken in relation to the perpetrator(s). This may include disciplinary action up to and including dismissal. The victim(s) will receive support and, if necessary, help with reintegration.

In any case, prevention measures to avoid or mitigate in the future psychosocial risks, work-related bullying among them, should always be considered along the process. Procedures on bullying complaints should be integrated in the psychosocial risks management of the company.

\section{REFERENCES}

[1] Article 32/2 of the Act on Wellbeing at Work (1996) amended by the laws of 28/02/2014 and 28/03/2014 http://www.emploi.belgique.be/defaultTab.aspx?id=564

[2] http://www.hsa.ie/eng/Publications_and_Forms/Publications/ Occupational_Health/CoP_Bullying.pdf

[3] https://www.ontario.ca/laws/statute/90o01

[4] http://www.secretariasenado.gov.co/senado/basedoc/ley_101 0_2006.html

[5] http://www.ohchr.org/Documents/Publications/GuidingPrinci plesBusinessHR_EN.pdf

[6] Ley Orgánica 3/2007 de Igualdad Efectiva entre Mujeres y Hombres

https://www.boe.es/buscar/doc.php?id=BOE-A-2007-6115

[7] ILO Code of Practice on workplace violence in services sector and measures to combat this phenomenon (2003) http://www.ilo.org/wcmsp5/groups/public/@ed_protect/@pr otrav/@safework/documents/normativeinstrument/wcms_10 7705.pdf

[8] http://www.europarl.europa.eu/hearings/20071121/femm/fra mework agreement en.pdf

[9] http://www.observatoriovascosobreacoso.com/2015/03/30/pr otocolo-de-prevencion-e-intervencion-del-observatorio-vasc o-sobre-acoso-frente-al-acoso-laboral-4/

[10] http://eur-lex.europa.eu/legal-content/EN/TXT/?uri=celex:31 989L0391 